\title{
Optimization of Parameters that Affect the Activity of the Alkaline Protease from Halotolerant Bacterium, Bacillus acquimaris VITP4, by the Application of Response Surface Methodology and Evaluation of the Storage Stability of the Enzyme
}

\author{
Jabeena Thaz Chittoor, Lavanya Balaji, Gurunathan Jayaraman * \\ Department School of Bio-Sciences and Technology, Vellore Institute of Technology, Vellore 632 014, India \\ ${ }^{*}$ Corresponding author: Gurunathan Jayaraman, Department School of Bio-Sciences and Technology, Vellore Institute of Technology, Vellore 632 014, \\ India. Tel: +91-4162202573, Fax: +91-4162243092, E-mail: gjayaraman@vit.ac.in
}

Received: June 24, 2015; Revised: December 08, 2015; Accepted: February 06, 2016

Background: It was previously shown that the activity of a serine protease from a moderately halotolerant Bacillus aquimaris VITP4 strain is active in a wide range of $\mathrm{pH}$ and temperatures and could be modulated by the presence of the divalent metal ions.

Objectives: In the present study, a quantitative analysis was done in order to explore the parameters that are contributing to the protease activity.

Materials and Methods: Changes in the secondary structure of the enzyme was determined by circular dichroism analysis. The conditions for the optimal activity was investigated by Response Surface Methodology. Stability of the enzyme was determined by thermal inactivation experiments.

Results: The initial one-factor-at-a-time experiments have indicated that the activity of the enzyme could be enhanced not only by the presence of low concentrations of $\mathrm{NaCl}$ but also by divalent metal ions, such as $\mathrm{Ca}^{2+}, \mathrm{Mn}^{2+}$ and $\mathrm{Cu}^{2+}$. $\mathrm{A}$ clear dependence of the activity to the secondary structure of the enzyme could be established using circular dichroism spectroscopy. In the next level of optimization, four factors; viz. $\mathrm{pH}$, temperature, concentration of $\mathrm{Ca}^{2+}$, and $\mathrm{Mn}^{2+}$ were used to optimize the conditions required for the maximal activity of the enzyme by Response Surface Methodology, and the data could be explained using quadratic model. Under optimal condition of $43^{\circ} \mathrm{C}, \mathrm{pH} 8.0,8.2 \mathrm{mM} \mathrm{Ca}^{2+}$, and $4.3 \mathrm{mM} \mathrm{Mn}^{2+} \mathrm{a}$ 1.5 times enhancement in the enzyme activity could be achieved. The storage stability of the enzyme under these selected conditions has indicated a non-linear relation between the conditions for the enzymatic activity as well as stability. However, the condition for the maximal stability $(267 \pm 18 \mathrm{~min})$ has corresponded to that of the optimal conditions for the maximal activity.

Conclusions: This study, for the first time, has explored the possibility of using statistical methods for identifying the optimal conditions for alkaline protease activity isolated from the halotolerant Bacillus aquimaris VITP4.

Keywords: Bacillus aquimaris VITP4; Circular dichroism; Divalent metal ions; Response surface methodology; Serine protease; Storage stability

\section{Background}

A great deal of efforts is focused on meeting the increasing demand for novel microbial catalysts that are capable of functioning under extreme conditions, and therefore, the production of these novel microbial enzymes with appreciable activity and stability in the harsh environments (1). Enzymes from organisms which can grow in $0-15 \%$ of the $\mathrm{NaCl}$ will have great potential for the use in the industries because of their inherent ability to be active and stable both in the pres- ence as well as in the absence of salt. However, most of these enzymes require metal ions for the maintenance of the structure and/or stability (2). These enzymes are active and stable under conditions that cause in a lower activity, which include high salt concentrations or organic solvents (3). In most of the cases, measurable proteolytic activity is achieved upon supplementation of cofactors like divalent metal ions in the assaying buffer. Also loss of enzymatic activity can be restored by incubating the enzyme with excess metal ions (4). 
Proteases hold a large potential for application in the food, dairy industries, detergent, and leather industries due to the increasing trend to develop environmentally friendly technologies (5). Study of the enzyme conformation using far UV circular dichroism (CD) and activity measurement as a function of $\mathrm{pH}$, metal ions, and other additives will help us in establishing the structure-function relationship of the enzymes (6). With proteases gaining considerable importance in the industrial market, efforts on optimizing enzyme activity has been focused with the use of different statistical software packages (7). Response surface methodology (RSM) is a collection of mathematical and statistical techniques useful for the modeling and analysis of the problems in which a response of interest is influenced by several variables. This methodology is finding its application in bioenergy, food, in addition to pharmaceutical researches $(8,9)$. In spite of the unique potential of the halotolerant enzymes, very little information is available in the literature to exploit the applicability of these enzymes in the industrial processes. In this regard, we have been focusing our attention to evaluate the utility of the halotolerant microbes and its metabolites. In our previous studies (10-12), we have reported the production of an extracellular protease by a halotolerant Bacillus aquimaris strain isolated from a saltern region of the Kumta coast (Karnataka, India). The serine protease produced by this organism was found to be active under a broader range of $\mathrm{pH}$ and temperature values, and also in the presence of the moderate salt concentrations $(10,11)$. Moreover, the enzyme has a predominant $\beta$-sheet secondary structure and was also shown to be tolerant to commercial detergents. The activity of the enzyme could also be enhanced in presence of $\mathrm{Ca}^{2+}$ ions. Uniquely, the enzyme could also be activated by the presence of $\mathrm{Mn}^{2+}$ and $\mathrm{Cu}^{2+}$ ions (12). Protease activation by $\mathrm{Mn}^{2+}$ ions is not commonly reported in the literature. The role of these divalent metal ions and their contribution to the overall activity of the enzyme needs to be explored. With this in view, the present study deals with optimization of the conditions, required for this metal ion activated serine protease from the halotolerant Bacillus aquimaris, for maximal activity. In addition, the effect of these combined parameters on the storage stability of the enzyme was also investigated. Enzymes from extremophiles have given us a scope to expand the reaction conditions and to meet growing industrial demands. The present study for the first time has used the statistical optimization protocols for achieving conditions required for the maximal activity of the enzyme and evaluation of the shelf life under different conditions.

\section{Objectives}

Enzymes from extremophiles have given us a scope to expand the reaction conditions and to meet growing industrial demands. The present study for the first time has used the statistical optimization protocols for achieving conditions required for the maximal activity of the enzyme and evaluation of the shelf life under different conditions.

\section{Materials and Methods}

\subsection{Chemicals and Software Used}

Media components were obtained from Hi-Media (Bombay, India). Graphs were plotted using the Graphpad Prism (version 5.0) and Design Expert Software (Trial version 9.0.2.0, Stat-Ease, Inc., Minneapolis, MN). Circular dichroism data were analyzed using Yang et al., 1986 (13).

\subsection{Protease Activity and Enzyme Purification}

Protease activity was measured using caseinolytic assay (14). Purification of the enzyme was done as described in our earlier studies (12) as a two step process. In short, the protein was precipitated with ammonium sulfate, followed by fractionation using gel filtration chromatography.

\subsection{Effect of EDTA and Activity Restoration by Metal} Ions and (ICP-AES) for Metal Content Determination

The presence of the metal ions $\left(\mathrm{Mn}^{2+}, \mathrm{Ca}^{2+}\right.$ and $\left.\mathrm{Cu}^{2+}\right)$ in the protein solution was determined by ICPAES (ARCOS, M/s. Spectro, Germany). Sample preparation involved extensive dialysis (membrane cutoff $10 \mathrm{kDa}$ ) against deionised water, followed by centrifugation at $8000 \mathrm{~g}$ for $5 \mathrm{~min}$ to remove any particulate matters. Metal ion depleted protease was prepared by extensive dialysis of the enzyme solution against $50 \mathrm{mM}$ Tris ( $\mathrm{pH} 8.0$ ) buffer containing $1 \mathrm{mM}$ EDTA for $6 \mathrm{~h}$ at $4^{\circ} \mathrm{C}$. The process was repeated three times by changing the buffer solution every one hour.

\subsection{Circular Dichroism}

CD spectra were recorded in a Jasco-J715 spectropolarimeter at room temperature $\left(25^{\circ} \mathrm{C}\right)$ using a $1 \mathrm{~cm}$ path length cell in the wavelength range of 190-260 nm. Each spectrum represented an average of five repetitive scans. Appropriate base line and blank subtractions were performed prior to analysis. The CD spectra of the 
protease under different environmental conditions were recorded in $10 \mathrm{mM}$ Tris buffer $(\mathrm{pH} \mathrm{8.0)}$ in the presence of the appropriate additives. Results are expressed as the mean residue ellipticity $\left(\theta\right.$, degree $\left.\mathrm{cm}^{-1} \mathrm{M}^{-1}\right)$.

\subsection{Experimental Design and Optimization by} Response Surface Methodology (RSM)

Preliminary information on the effect of metal ions was obtained by one-factor-at-a-time methodology. The important factors were screened among Temperature, $\mathrm{pH}, \mathrm{CaCl}_{2}, \mathrm{MnCl}_{2}, \mathrm{CuCl}_{2}$, and $\mathrm{NaCl}$ by Plackett-Burman (PB) factorial design and further optimization was done using central composite design (CCD) $(15,16)$.

\subsubsection{Plackett-Burman Design}

Fractional design was used at 2 levels to screen multiple factors to find the significant ones and effects of all interactions were estimated using full factorial. Temperature, $\mathrm{pH}, \mathrm{CaCl}_{2}, \mathrm{MnCl}_{2}, \mathrm{CuCl}_{2}$, and $\mathrm{NaCl}$ were selected to infer the most important factors that affect the enzyme activity. The response value given in these experiments was an average of the triplicate measurements and the results were analyzed and interpreted using the Design Expert Software (Trial version 9.0.2.0, Stat-Ease, Inc., Minneapolis, MN).

\subsubsection{Optimization by Central Composite Design (CCD) and Model Validation}

The screened variables influencing enzyme activity were further optimized using Central composite design (CCD). CCD estimates the quadratic response surface from which factor levels for the maximum hydrolytic activity could be determined. With the central composite design, the second order polynomial relationship between the factors and the dependent variables established, gives an idea about the interaction between variables (17).

The experimental data were analyzed using response surface methodology, in order to calculate the coefficients of the second order polynomial equation:

$$
Y=\beta_{0}+\sum_{i=1}^{4} \beta_{i} X_{i}+\sum_{i=1}^{4} \beta_{i i} X_{i}^{2}+\sum_{i, j=1}^{4} \beta_{i j} X_{i} X_{j}
$$

In this equation $\mathrm{Y}$ is the response factor, $\mathrm{i}$ and $\mathrm{j}$ indicated coded factors of the system and $X_{i}$ and $X_{j}$ representing the independent coded variables. $\beta_{0}$, is the interception coefficient and $\beta_{\mathrm{i}} \beta_{\mathrm{ii}}$ and $\beta_{\mathrm{ij}}$ are coefficients of linear, quadratic and interaction effects.

The Design Expert version 9.0.2.0 (Stat-Ease Inc.,
Minneapolis, USA) statistic software program was used to calculate the regression and graphical analysis of the obtained data and their significance was verified using analysis of variance (ANOVA). Through validation, the efficiency of the model was evaluated by comparing the predicted results with the experimental data. The model was validated under optimum conditions and the quality of fit of the second order equation was expressed as the coefficient of determination $\mathrm{R}^{2}$ $(2,7,18)$.

\section{Results}

\subsection{Reactivation of Metal Ion Depleted Enzyme by Metal Ions}

Quantification of the enzyme bound metal ion was performed using inductive coupled plasma atomic emission spectrometry (ICP-AES). The enzyme was found to contain $1.04 \mathrm{~mol} \mathrm{Ca}^{2+}, 0.5 \mathrm{~mol}$ of $\mathrm{Cu}^{2+}$ and $0.126 \mathrm{~mol}$ of $\mathrm{Mn}^{2+}$ (per mole of enzyme). This indicates that the protease has preference for $\mathrm{Ca}^{2+}$ and could accommodate $\mathrm{Mn}^{2+}$ as well. In order to get further insight on the role of these metal ions on the enzyme activity, the enzyme activity was assayed after incubating the metal ion depleted enzyme in the presence of these metal ions, either individually or as a linear combination of these ions. The protein dialyzed against $10 \mathrm{mM}$ Tris buffer ( $\mathrm{pH} 8.0$ ) containing $1 \mathrm{mM}$ EDTA resulted in a loss of $88 \%$ of activity. However, addition of $\mathrm{Mn}^{2+}$ and $\mathrm{Ca}^{2+}$, either individually or in combination, was found to restore the activity of the enzyme (Table 1). Addition of $\mathrm{Cu}^{2+}$ did not improve the activity, even though the presence of low concentrations of the $\mathrm{Cu}^{2+}$ could enhance the enzyme activity (12). This reflects the differential role of the metal ions played in restoring the enzyme activity. Similar metal ion dependent activity was observed with endopepti-

Table 1. Effect of $\mathrm{Mn}^{2+}, \mathrm{Ca}^{2+}$, and $\mathrm{Cu}^{2+}$ on the recovery of the protease activity. Metal ion depleted enzyme was prepared by the repeated dialysis against $1 \mathrm{mM}$ EDTA

\begin{tabular}{lccc}
\hline Metal ions & \multicolumn{3}{c}{ Original activity restored (\%) } \\
\cline { 2 - 4 } & $\mathbf{1 ~} \mathbf{~ m M}$ & $\mathbf{5 ~} \mathbf{~ M}$ & $\mathbf{1 0} \mathbf{~ m M}$ \\
\hline $\mathrm{Mn}^{2+}$ & $30.3 \pm 2.2$ & $30.3 \pm 2.2$ & $71.9 \pm 2.2$ \\
$\mathrm{Ca}^{2+}$ & $26.9 \pm 1.9$ & $26.9 \pm 1.9$ & $66.2 \pm 2.5$ \\
$\mathrm{Cu}^{2+}$ & $13.7 \pm 1.5$ & $13.7 \pm 1.5$ & $8.4 \pm 0.8$ \\
$\left(\mathrm{Ca}^{2++} \mathrm{Mn}^{2+}\right)^{*}$ & $38.8 \pm 1.6$ & $38.8 \pm 1.6$ & $89.9 \pm 1.7$ \\
\hline
\end{tabular}

$\left(\mathrm{Ca}^{2+} \text { and } \mathrm{Mn}{ }^{2+}\right)^{*}$ : Concentration is cumulative of both the metal ions in 1:1 ratio 
dase of Bacillus cereus JH108 wherein the loss of activity upon exposure to EDTA was completely restored by addition of $1 \mathrm{mM} \mathrm{Ca}{ }^{2+}$ and partially restored by $\mathrm{Co}^{2+}$ and $\mathrm{Mn}^{2+}$ (4). Earlier reports support the fact that $\mathrm{Ca}^{2+}$ plays an important role in protecting the enzyme from auto proteolysis. Also depletion of $\mathrm{Ca}^{2+}$ lowers the specific activity and the thermal stability of the enzyme (22).

\subsection{Analysis of the Secondary Structure of the Protease in the Presence of $\mathrm{Ca}^{2+}$}

In order to draw a correlation between the observed activity and the secondary structure content of the enzyme, circular dichroism spectra were recorded in the far UV region $(200-250 \mathrm{~nm})$. The $\beta$-sheet content in the enzyme was found to be different in the presence of the metal ions/inhibitors (Table 2). Irrespective of the metal ion used, the observed changes in the structure reflected in the enhancement or reduction in the enzymatic activity. The presence of inhibitors reduced the $\beta$-sheet content and also the proteolytic activity. Similar observations were reported for $B$. cereus SIU1 serine protease in which the decrease in the $\beta$-sheet content was correlated to decrease in the enzyme activity (6). High $\beta$-sheet content was reported for serine protease isolated from halophilic Virgibacillus and the $\beta$-sheet content was reduced in the absence of $\mathrm{NaCl}$ which in turn resulted in a poor activity (23).

It should be pointed out that the secondary structure of the enzyme and the activity was found to be unaffected even after prolonged storage for 12 months at $4^{\circ} \mathrm{C}$. However, extensive dialysis against $10 \mathrm{mM}$ Tris buffer with $5 \mathrm{mM}$ EDTA resulted in complete loss of $\beta$-sheet structure and therefore loss of activity, thus indicating the requirement of the metal ions for activity and storage stability of the enzyme.

Table 2. Secondary structural composition (\%) of the protease $(0.2$ $\left.\mathrm{mg} . \mathrm{mL}^{-1}\right)$ probed by circular dichroism in the presence of different additives

\begin{tabular}{|c|c|c|c|c|c|}
\hline \multirow{2}{*}{$\begin{array}{l}\text { Environmental } \\
\text { conditions }\end{array}$} & \multicolumn{4}{|c|}{ Secondary structure composition (\%) } & \multirow{2}{*}{$\begin{array}{c}\text { Activity } \\
(\%)\end{array}$} \\
\hline & $\alpha$-Helix & $\beta$-Sheets & Turns & Random & \\
\hline $\mathrm{pH} 8.0$ & 12.6 & 12.6 & 16.7 & 29.9 & 100 \\
\hline $\mathrm{Ca}^{2+}(1 \mathrm{mM})$ & 9.4 & 9.4 & 12.1 & 27.0 & 10 \\
\hline $\mathrm{Mn}^{2+}(1 \mathrm{mM})$ & 10.6 & 10.6 & 13.2 & 28.5 & 103 \\
\hline $\mathrm{Cu}^{2+}(1 \mathrm{mM})$ & 10.2 & 10.2 & 11.6 & 21.8 & 115 \\
\hline EDTA (1 mM) & 14.9 & 14.9 & 15.8 & 32.2 & 36 \\
\hline $\begin{array}{l}\text { 1,10-Phenan } \\
(\mathrm{mM})\end{array}$ & 12.5 & 12.5 & 16.0 & 39.2 & 69 \\
\hline
\end{tabular}

4.3. Optimization of Protease Activity by Response Surface Methodology

Based on the preliminary results, a screening experiment using Plackett Burman design was employed to identify factors (i.e. temperature, $\mathrm{pH}, \mathrm{CaCl}_{2}, \mathrm{MnCl}_{2}$, $\mathrm{CuCl}_{2}$, and $\mathrm{NaCl}$ ) that affect the enzyme activity significantly. A total of 8 runs were used to evaluate 6 variables which were tested at two levels. From the Pareto chart (Figure 1), the most effective factors with high significance for proteolytic activity were $\mathrm{pH}$, Temperature, concentration of $\mathrm{CaCl}_{2}$, and $\mathrm{MnCl}_{2}$.

The significance of each term was determined using $\mathrm{p}$ values and values of 'Prob $>\mathrm{F}$ ' less than 0.0500 indicates that the model terms are significant. The F-value of 285.44 implies the model is significant. There is only a $4.53 \%$ chance that an F-value this large could occur due to noise. The Pred R-Square of 0.96 is in reasonable agreement with the Adj R-Squared of 0.99 . Adequate precision ratio of 49.57 indicates an adequate signal.

Based on the Plackett Burman design, temperature, $\mathrm{pH}$, concentration of $\mathrm{CaCl}_{2}$, and $\mathrm{MnCl}_{2}$ were chosen for further optimization by RSM. Central composite design (CCD) was employed within a specified range to check the combined effect of these factors on protease activity; the results of which are given in (Table $3)$.

In order to determine if a relationship existed between the factors and the response investigated, the collected data were analyzed statistically using regression analysis, which showed that the selected quadratic model was appropriate to describe the system. Consequently the following second order polynomial model was proposed.

Protease activity $=+93.5-3.17 \mathrm{~A}+3.25 \mathrm{~B}-2.42 \mathrm{C}-$ $2.58 \mathrm{D}+0.88 \mathrm{AB}-0.25 \mathrm{AC}+0.63 \mathrm{AD}+0.50 \mathrm{BC}+$

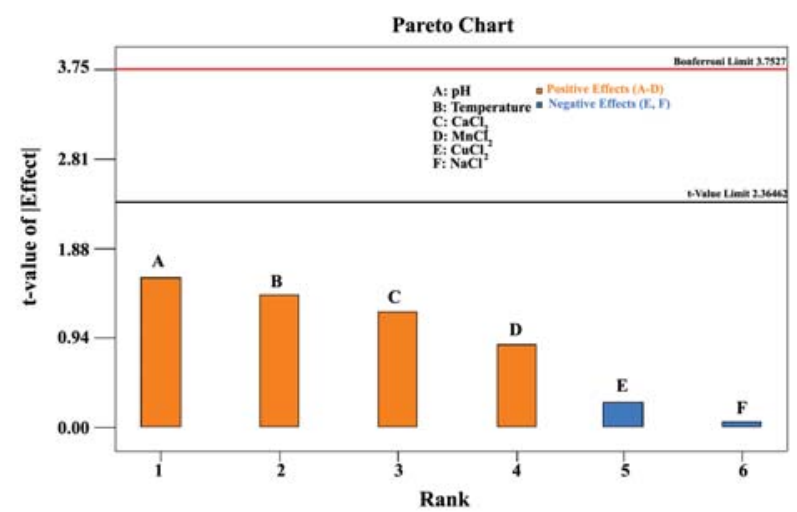

Figure 1. Pareto chart for the Plackett Burman design. The figure depicts the effect of 6 variables on protease activity 
Table 3. Secondary structural composition (\%) of the protease $(0.2$ $\mathrm{mg} . \mathrm{mL}^{-1}$ ) probed by circular dichroism in the presence of different additives

\begin{tabular}{|c|c|c|c|c|c|c|}
\hline \multirow[t]{2}{*}{ Run } & \multirow{2}{*}{$\begin{array}{c}\text { A } \\
\text { (Temp.) }\end{array}$} & \multirow{2}{*}{$\begin{array}{c}\mathrm{B} \\
(\mathrm{pH})\end{array}$} & \multirow{2}{*}{$\begin{array}{c}\mathrm{C} \\
\left(\mathrm{Ca}^{2+}\right)\end{array}$} & \multirow{2}{*}{$\begin{array}{c}\mathrm{D} \\
\left(\mathrm{Mn}^{2+}\right)\end{array}$} & \multicolumn{2}{|c|}{ Protease Activity (U.mL $\left.\mathrm{mL}^{-1}\right)$} \\
\hline & & & & & Experimental & Predicted \\
\hline 1 & 0 & 0 & 0 & 0 & $93.1 \pm 0.8$ & 93.5 \\
\hline 2 & 0 & 0 & 0 & 0 & $94.3 \pm 1.2$ & 93.5 \\
\hline 3 & -1 & -1 & 1 & -1 & $75.7 \pm 1.1$ & 72.7 \\
\hline 4 & 0 & 0 & 0 & 0 & $93.3 \pm 1.1$ & 93.5 \\
\hline 5 & 1 & 1 & -1 & -1 & $76.5 \pm 1.0$ & 66.2 \\
\hline 6 & -1 & -1 & -1 & -1 & $71.4 \pm 1.3$ & 72.5 \\
\hline 7 & 1 & -1 & 1 & -1 & $66.1 \pm 0.8$ & 62.8 \\
\hline 8 & 1 & 1 & 1 & -1 & $69.1 \pm 0.4$ & 67.4 \\
\hline 9 & 0 & 0 & 0 & -2 & $79.3 \pm 2.0$ & 85.5 \\
\hline 10 & 0 & 2 & 0 & 0 & $59.4 \pm 0.9$ & 60.7 \\
\hline 11 & 0 & 0 & 0 & 0 & $92.6 \pm 0.8$ & 93.5 \\
\hline 12 & -2 & 0 & 0 & 0 & $75.5 \pm 0.8$ & 66.4 \\
\hline 13 & -1 & 1 & 1 & 1 & $65.3 \pm 1.6$ & 66.5 \\
\hline 14 & 0 & 0 & 0 & 2 & $77.8 \pm 1.2$ & 75.3 \\
\hline 15 & 1 & -1 & -1 & 1 & $64.6 \pm 1.6$ & 60.5 \\
\hline 16 & 0 & 0 & 0 & 0 & $94.2 \pm 0.7$ & 102 \\
\hline 17 & 1 & -1 & -1 & -1 & $69.2 \pm 2.1$ & 63.7 \\
\hline 18 & 2 & 0 & 0 & 0 & $40.0 \pm 2.1$ & 53.4 \\
\hline 19 & -1 & 1 & -1 & 1 & $73.7 \pm 2.4$ & 75.4 \\
\hline 20 & 0 & 0 & -2 & 0 & $69.2 \pm 0.7$ & 75.6 \\
\hline 21 & -1 & 1 & 1 & -1 & $71.2 \pm 1.2$ & 73.7 \\
\hline 22 & 0 & 0 & 0 & 0 & $95.4 \pm 1.4$ & 93.5 \\
\hline 23 & 1 & 1 & -1 & 1 & $74.3 \pm 1.4$ & 72.5 \\
\hline 24 & 0 & -2 & 0 & 0 & $45.8 \pm 2.1$ & 47.7 \\
\hline 25 & 0 & 0 & 2 & 0 & $68.1 \pm 1.4$ & 65.9 \\
\hline 26 & 1 & 1 & 1 & 1 & $65.8 \pm 1.8$ & 62.7 \\
\hline 27 & -1 & 1 & -1 & -1 & $71.1 \pm 0.9$ & 71.5 \\
\hline 28 & -1 & -1 & -1 & 1 & $69.4 \pm 1.9$ & 68.8 \\
\hline 29 & 1 & -1 & 1 & 1 & $53.3 \pm 1.6$ & 48.7 \\
\hline 30 & -1 & -1 & 1 & 1 & $47.7 \pm 1.2$ & 56.0 \\
\hline
\end{tabular}

2.38BD - 2.75CD - 8.44A $-9.81 \mathrm{~B}^{2}-5.69 \mathrm{C}^{2}-3.31 \mathrm{D}^{2}$

In the above equation the variables $\mathrm{A}, \mathrm{B}, \mathrm{C}$, and $\mathrm{D}$ represents the coded levels of temperature, $\mathrm{pH}, \mathrm{CaCl}_{2}$, $\mathrm{MnCl}_{2}$, respectively.

The association between response (proteolytic activity) of the predicted and experimental data under these conditions is shown in (Table 3 ). The accuracy of the model was validated by the analysis of variance, using high $\mathrm{F}$ value (10.43) which implies the model is significant and there is only a $0.01 \%$ chance that an Fvalue this large could occur due to noise, very low $\mathrm{P}$ value $(<0.0001)$, and a regression coefficient $\left(\mathrm{R}^{2}=0.9068\right)$. Probability value less than 0.0500 indicates the model terms are significant. In this case, A, $\mathrm{B}, \mathrm{C}, \mathrm{D}, \mathrm{A}^{2}, \mathrm{~A}^{2}, \mathrm{C}^{2}$ are the significant model terms. The "Lack of Fit F-value" of 56.35 implies the significance. The signal to noise ratio of 10.2 indicates an adequate signal. This model can be used to navigate the design space and can be used for prediction of the protease activity under the desired conditions.

\subsection{Interaction Effects of Variables on the Activity of Protease}

The 3D surface plots developed from the regression model were used to predict the influence of different variables on protease activity. Through surface plots, it is evident that the interaction among variables has influenced the protease activity. The surface plots in (Figure 2A) shows the interaction between $\mathrm{pH}$ and temperature keeping the other two variables at constant and appears to have a single optimum point. The non-linear nature of the surface implies that the interactions between the selected variables are important. As well, it also indicates that an increase in the temperature has enhanced the activity at low $\mathrm{pH}$ level, but when the temperature has increased, this effect was found to decrease. The interaction between $\mathrm{pH}$ and temperature could be inferred from the response along the axis. The predicted protease activity $\left(87 \mathrm{U} \cdot \mathrm{mL}^{-1}\right)$ was obtained at the central point of $\mathrm{A}\left(52^{\circ} \mathrm{C}\right)$ and $\mathrm{B}$ (8.0), respectively.

The combined effect of $\mathrm{CaCl}_{2}$ and temperature on protease activity can be depicted from (Figure 2B).
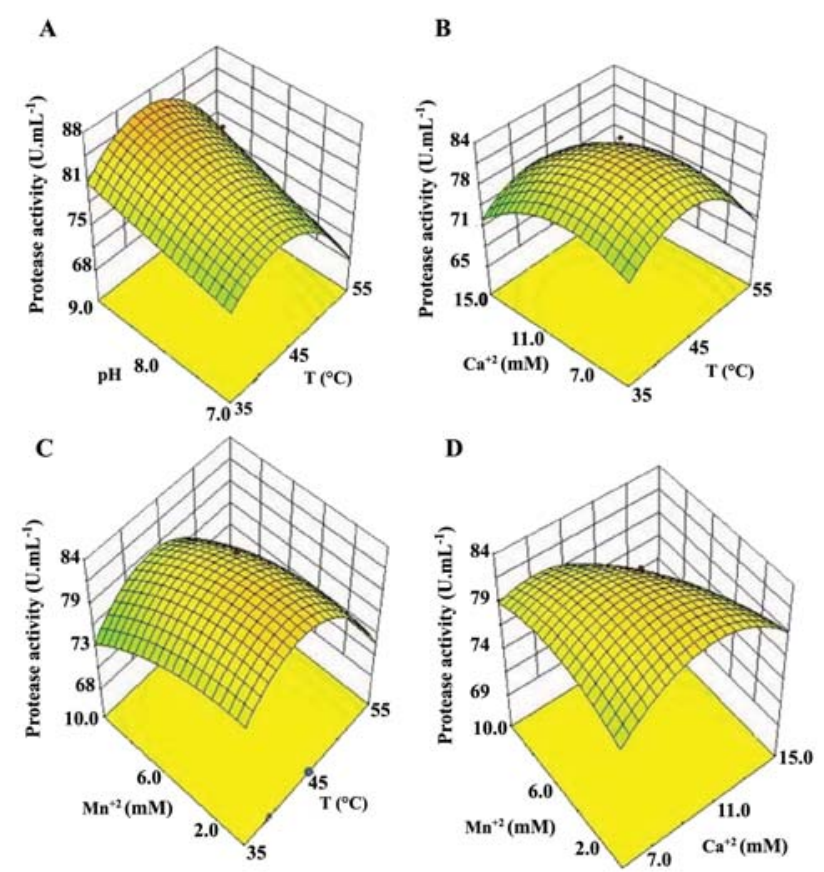

Figure 2. Response surface plots for the protease activity obtained from optimization studies. A: interaction of temperature and $\mathrm{pH}$; $\mathrm{B}$ : interaction of temperature and $\mathrm{CaCl}_{2} ; \mathrm{C}$ : interaction of $\mathrm{MnCl}_{2}$ and temperature; $\mathrm{D}$ : interaction of $\mathrm{CaCl}_{2}$ and $\mathrm{MnCl}_{2}$ 
The maximum protease activity $\left(90.3 \mathrm{U} \cdot \mathrm{mL}^{-1}\right)$ was observed at $51^{\circ} \mathrm{C}$ and $6.8 \mathrm{mM} \mathrm{CaCl}_{2}$ through response surface plot analysis. Increased concentration of $\mathrm{CaCl}_{2}$ has resulted in a significant positive effect on protease activity at low temperature, but a reduction in the activity was observed as the concentration of $\mathrm{CaCl}_{2}$ was further increased. Though the surface plots have considerable curvature, the corresponding p-values indicate that the interaction between these two parameters is not statistically significant.

Figure $2 \mathrm{C}$ represents the responses obtained from the interaction of $\mathrm{MnCl}_{2}$ and temperature. It can be inferred that increase in the temperature has improved the activity at low levels of $\mathrm{MnCl}_{2}$, however, with further increase in the concentration of $\mathrm{MnCl}_{2}$ a reduction in the activity could be observed. This could imply that these metal ions could impose a stabilizing effect on the enzyme. Our previous studies have indicated that the enzymatic activity of this protease was completely inhibited by PMSF and not by any of the metal ion chelating agents (12), thereby confirming that these metal ions plays a stabilizing role, and are not directly involved in the enzymatic activity. However, decrease in the enzyme activity upon a further increase in the metal ion concentration could be due to an increased ionic strength in the medium which might be detrimental to either the enzyme structure or substrate binding. The curves also suggest that an increased concentration of $\mathrm{MnCl}_{2}$ did not vary enzyme's response significantly. The combined effect of $\mathrm{CaCl}_{2}$ and $\mathrm{MnCl}_{2}$ on protease activity can be inferred from (Figure 2D). The surface plot does not have a considerable curvature, implying that the interaction between selected variables is not significant. This is also evident from the ANOVA table (Table 4) where the F-value of the interaction of these variables was found to be larger than 0.05 . Thus the plots suggest that the variables elicit independent effects on the enzyme activity. Thermal fluctuations play an important role in the enzyme activity. It is obvious that increase in temperature increases the disorder in the amino acids' side chain, if not the main chain of the protein. Consequently, the binding of the substrate to the enzyme decreases, thereby results in a decreased enzyme activity.

\subsection{Validation of the Model}

Validation of the response surface model was performed with a random set of experiments (Table 5).

Table 4. Analysis by ANOVA for Response Surface Quadratic model. The P-value indicates the statistical significance of the parameters that affect the enzyme activity. The significance of the interaction between the parameters can also be inferred

\begin{tabular}{|c|c|c|c|c|c|}
\hline & Source & $\begin{array}{l}\text { Sum of } \\
\text { Squares }\end{array}$ & DF & Mean Square & P- Value \\
\hline Model & 6085.33 & 14.00 & 434.67 & 10.43 & $<0.0001$ \\
\hline A-Temp. & 204.17 & 1.00 & 204.17 & 4.90 & 0.0428 \\
\hline B-pH & 216.00 & 1.00 & 216.00 & 5.18 & 0.0379 \\
\hline $\mathrm{C}-\mathrm{Ca}^{2+}$ & 468.17 & 1.00 & 468.17 & 11.23 & 0.0043 \\
\hline D-Mn²+ & 352.67 & 1.00 & 352.67 & 8.46 & 0.0108 \\
\hline$A B$ & 4.00 & 1.00 & 4.00 & 0.10 & 0.7610 \\
\hline$A C$ & 0.25 & 1.00 & 0.25 & 0.01 & 0.9392 \\
\hline$A D$ & 1.00 & 1.00 & 1.00 & 0.02 & 0.8789 \\
\hline B C & 0.25 & 1.00 & 0.25 & 0.01 & 0.9392 \\
\hline B D & 121.00 & 1.00 & 121.00 & 2.90 & 0.1090 \\
\hline C D & 156.25 & 1.00 & 156.25 & 3.75 & 0.0719 \\
\hline $\mathrm{A} 2$ & 2050.30 & 1.00 & 2050.30 & 49.18 & $>0.0001$ \\
\hline B2 & 2754.30 & 1.00 & 2754.30 & 66.07 & $>0.0001$ \\
\hline B2 & 913.44 & 1.00 & 913.44 & 21.91 & 0.0003 \\
\hline D2 & 112.01 & 1.00 & 112.01 & 2.69 & 0.1220 \\
\hline Residual & 625.33 & 15.00 & 41.69 & & \\
\hline Pure Error & 5.50 & 5.00 & 1.10 & & \\
\hline Cor Total & 6710.67 & 29.00 & & & \\
\hline Std. Dev. & & 6.46 & R-Squared & & 0.9068 \\
\hline Mean & & 72.33 & Adj R-Squared & & 0.8198 \\
\hline C.V.\% & & 8.93 & Pred R-Squared & & 0.4668 \\
\hline PRESS & & 3578.16 & Adeq Precision & & 10.2397 \\
\hline
\end{tabular}


Table 5. The predicted and experimental values of the protease production by the halotolerant strain

\begin{tabular}{lcccccc}
\hline $\begin{array}{l}\text { Run } \\
\text { no. }\end{array}$ & A & B & C & D & \multicolumn{2}{c}{ Protease Activity } \\
\hline 1 & 43 & 8.2 & 8.2 & 4.3 & $98.2 \pm 2.2$ & 95.0 \\
2 & 43 & 8.0 & 9.0 & 2.6 & $93.3 \pm 2.5$ & 95.0 \\
3 & 43 & 8.0 & 7.7 & 3.8 & $91.1 \pm 2.2$ & 95.0 \\
4 & 43 & 8.0 & 8.2 & 4.0 & $97.1 \pm 2.5$ & 95.0 \\
5 & 50 & 7.9 & 6.6 & 3.8 & $86.4 \pm 1.8$ & 90.0 \\
6 & 55 & 7.4 & 8.7 & 5.8 & $69.9 \pm 2.0$ & 77.0 \\
7 & 54 & 8.4 & 8.0 & 5.0 & $78.5 \pm 2.7$ & 85.0 \\
8 & 50 & 8.0 & 6.5 & 8.9 & $78.3 \pm 2.1$ & 87.0 \\
\hline
\end{tabular}

$\mathrm{R}^{2}=0.9257$

The observed value of $98.2 \mathrm{U} \cdot \mathrm{mL}^{-1}$ is closer to the predicted value of $95.0 \mathrm{U} \cdot \mathrm{mL}^{-1}$, with the relative standard error percentage of the $3.3 \%$. The above results confirm the adequacy of RSM for designing and optimizing the enzymatic process. The optimized condition obtained for the protease activity was as follows: temperature $\left(43^{\circ} \mathrm{C}\right), \mathrm{pH}(8.0), \mathrm{CaCl}_{2}$ (8.2) and $\mathrm{MnCl}_{2}$ (4.3). The process resulted in a 1.5 fold (65.5 to $98.2 \mathrm{U}^{\mathrm{mL}} \mathrm{m}^{-1}$ ) increased enzymatic protease activity of the extracellular protease produced by Bacillus aquimaris VITP4 strain.

This work is the first attempt for optimizing protease activity from halotolerant bacterium B.aquimaris VITP4 strain using response surface methodology.

\subsection{Evaluation of the Protease Storage Stability}

The storage stability of the extracellular protease produced by $B$. aquimaris VITP4 (Table 6) was evaluated under a range of conditions. Though not necessary, it was found that the activity displayed a linear relationship with the half life of the enzyme, with a linear regression value of 0.80 (Figure 3 ). The stability of the protease was found to be less at pH 6.0 and 10.0 (Table 6) when compared to $\mathrm{pH}$ 8.0. The protease shows a maximum half life

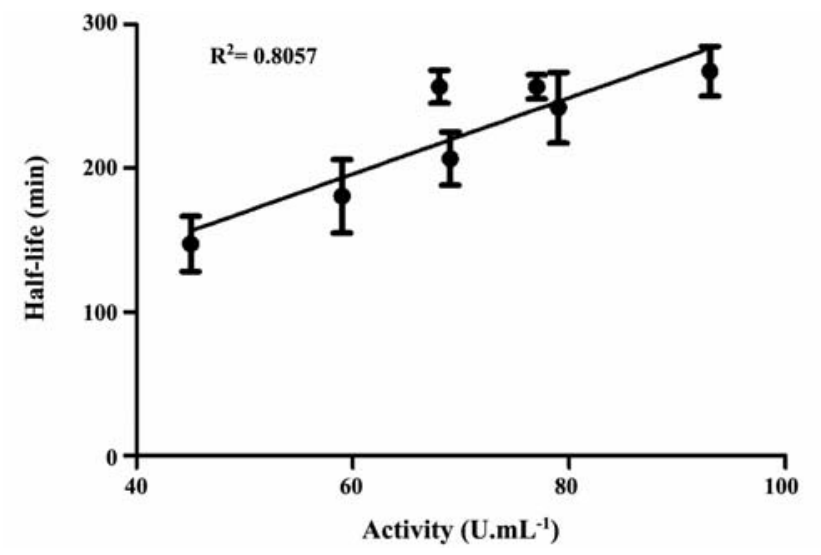

Figure 3. The relationship between activity and the half-life of the enzyme. The relation between these two factors could be described by a linear relation

of $267.2 \pm 18.4 \mathrm{~min}$ at temp $45^{\circ} \mathrm{C}, \mathrm{pH} 8.0 ; \mathrm{Ca}^{2+}(10 \mathrm{mM})$ and $\mathrm{Mn}^{2+}(5 \mathrm{mM})$, followed by $256.6 \pm 11.3 \mathrm{~min}$ at $45^{\circ} \mathrm{C}$, $\mathrm{pH}$ 8.0, $\mathrm{Ca}^{2+}(10 \mathrm{mM})$ and $\mathrm{Mn}^{2+}(15 \mathrm{mM})$ and $256.2 \pm 10.6 \mathrm{~min}$ at temp $45^{\circ} \mathrm{C}, \mathrm{pH} 8.0, \mathrm{Ca}^{2+}(20 \mathrm{mM})$ and $\mathrm{Mn}^{2+}(5 \mathrm{mM})$. Temperature of $45^{\circ} \mathrm{C}$ and $\mathrm{pH} 8.0$ seems to be critical for the stability of the enzyme. As well, there could be seen variations in the half life as a function of the metal ions $\left(\mathrm{Ca}^{2+} / \mathrm{Mn}^{2+}\right)$ concentrations. It needs to be mentioned that the half life of the enzyme (pH 8.0) is $202.4 \pm 10.2 \mathrm{~min}$ in the absence of both $\mathrm{CaCl}_{2}$ and $\mathrm{MnCl}_{2}$, which is statistically similar to the stability in the presence of $5 \mathrm{mM} \mathrm{MnCl}_{2}$.

\section{Discussion}

Metal ion dependent activity was observed for the protease was observed for the protease from $B$. laterosporus (19); protease from the moderately haloalkali thermotolerant B.strain SH1 (20); halotolerant protease from $B$. cereus SIU1 (6) as well as alkaline protease from Bacillus circulans L (21). Earlier reports support the fact that $\mathrm{Ca}^{2+}$ plays an important role in protecting the enzyme from auto proteolysis.

\begin{tabular}{|c|c|c|c|c|c|c|}
\hline Run & Temperature $\left({ }^{\circ} \mathrm{C}\right)$ & $\mathrm{pH}$ & $\mathrm{Ca}^{2+}(\mathrm{mM})$ & $\mathrm{Mn}^{2+}(\mathrm{mM})$ & Activity (U.mL ${ }^{-1}$ ) & $\mathrm{t} 1 / 2(\min )$ \\
\hline 1 & 45 & 8.0 & 10 & 5 & $93.1 \pm 0.8$ & $267.2 \pm 18.4$ \\
\hline 2 & 45 & 8.0 & 10 & 0 & $79.3 \pm 2.0$ & $251.2 \pm 24.2$ \\
\hline 3 & 45 & 10.0 & 10 & 5 & $58.5 \pm 0.9$ & $180.6 \pm 26.7$ \\
\hline 4 & 45 & 8.0 & 10 & 15 & $77.7 \pm 1.2$ & $256.6 \pm 11.3$ \\
\hline 5 & 45 & 8.0 & 0 & 5 & $69.2 \pm 2.1$ & $205.7 \pm 18.4$ \\
\hline 6 & 45 & 6.0 & 10 & 5 & $45.8 \pm 2.2$ & $147.8 \pm 19.7$ \\
\hline 7 & 45 & 8.0 & 20 & 5 & $68.1 \pm 1.4$ & $256.2 \pm 10.6$ \\
\hline
\end{tabular}


Also depletion of $\mathrm{Ca}^{2+}$ lowers the specific activity and the thermal stability of the enzyme (22). High $\beta$-sheet content was reported for serine protease isolated from halophilic Virgibacillus and the $\beta$-sheet content was reduced in the absence of $\mathrm{NaCl}$ which in turn resulted in a poor activity (23).

There are numerous literatures available on optimization of the protease production using RSM (2426). Optimization of the activity by RSM is a time and material saving, efficient method, and yields a better understanding of the interactions among the variables. There are few reports in the literature in which RSM was successfully employed for optimization of the enzyme activity and consequently have achieved the highest product formation. Badoei-Dalfard et al. 2013 (7) have reported a 2.5 fold increase in protease activity by Bacillus sp. JER02 with statistical optimization by RSM. The RSM was also employed for optimizing conditions for enzymatic hydrolysis of the blood cells wherein a 40.46 times increase in the production of the free amino acids was achieved (27). Using a two-step response surface methodology (RSM), the condition for an optimum keratinase activity was optimized (28). The method was also used for optimizing hydrolysis conditions of the cockle (Anadara granosa) using Alcalase (29). The presence of the divalent calcium ion has been found to enhance the secretion of the protease in the production medium (30). In a few cases, the medium containing natural substrates such as fishbased medium (31) or vegetable wastes (32) have also been considered for optimizing production of the proteases. The production/activity of the most of these serine proteases was found to be dependent on the concentration of the divalent calcium ions.

It is desirous that the biocatalysts need to have adequate storage as well as operational process, operational stability, so that their applicability at a high temperature, extreme $\mathrm{pH}$, compatibility with organic solvent, and detergent can find suitable application in therapeutics, diagnostics, peptide synthesis, detergent formulations $(33,34)$. Crude preparations are generally more stable than the purified enzymes. Therefore storage requirements of the purified enzymes are of the prime concern to enzyme manufacturers (35). Majority of the proteins exhibit decreased stability when are not in their native environment. Such loss in the activity is envisaged to be the result of the proteolysis and aggregation. However, the activity can be maintained if buffers are supplemented with the metal ions that generally increase their stability and therefore their shelf life.

The methyl aminopeptidase from Pyrolobus furio- sus was reported to have a decreased stability at low $\mathrm{pH}$ values due to the protonation of the acidic residues which will invariably disrupt the favorable ionic interactions (36). A change in $\mathrm{pH}$ value apart from the optimum $\mathrm{pH}$ can protonate or deprotonate a side group, thereby a change in the activity or stability of an enzyme results because of a change in its chemical features. Alkaline serine protease from B. amyloliquefaciens $\mathrm{S} 94$ has found to exhibit the optimum activity at $\mathrm{pH} 8.0$, but show a lower activity at both low and high $\mathrm{pH}$ values, as well, to retain only $63 \%$ of the activity at $\mathrm{pH} 11$, but do not show any activity at $\mathrm{pH} 12.0$ (37). Recently, the thermal stability of an alkaline protease from halotolerant Bacillus sp. strain NPST-AK15 was shown to increase by two folds in the presence of calcium ions $(38,39)$.

There are reports indicating an increase in the half life of an enzyme through supplementation of different metal ions. The protease from Bacillus cereus WQ9-2 was seen to have a half life of $11 \mathrm{~min}$ at $60^{\circ} \mathrm{C}$ which increases to $360 \mathrm{~min}$ in the presence of $10 \mathrm{mM} \mathrm{Ca}^{2+}$. Addition of $\mathrm{Ca}^{2+}$ or $\mathrm{Mn}^{2+}$ have resulted in the stability of EA.1 proteinase over $75 \mathrm{~min}$ at $80^{\circ} \mathrm{C}(40)$. Alkaline protease from Bacillus brevis 6 was found to be stable for $288 \mathrm{~h}$ when incubated at $25^{\circ} \mathrm{C}$, but displayed half lives of 6 and $7 \mathrm{~h}$ at 50 and $60^{\circ} \mathrm{C}$. In addition to this, the thermostability of the enzyme was found to increase in the presence of $\mathrm{Ca}^{2+}$ and $\mathrm{Na}^{2+}$ (41). The alkaline protease from $B$. clausii $\mathrm{I}-52$ showed a half life of $150 \mathrm{~h}, 6.5 \mathrm{~h}, 1.5 \mathrm{~h}$ and $0.6 \mathrm{~h}$ at $45,50,55$ and $60^{\circ} \mathrm{C}$, respectively. The presence of $\mathrm{Ca}^{2+}$ has increased the half life of $20 \mathrm{~min}$ at $50^{\circ} \mathrm{C}$ to $26 \mathrm{~min}$ for subtilisin (42). The above literatures support the fact that increased stability of the enzyme can be achieved upon supplementation of the required metal ions.

\section{Conclusions}

Proteases, in general, are activated by $\mathrm{Ca}^{2+}$ ions; few of which are modulated by $\mathrm{Mn}^{2+}$. Though the enzyme is active under saline conditions, the activity was not perturbed significantly in the presence of $\mathrm{NaCl}$. The enzyme was found to display maximum activity of $98.2 \pm 2.2 \mathrm{U}_{\mathrm{mL}}^{-1}$ at $43^{\circ} \mathrm{C}, \mathrm{pH} 8.0,8.2 \mathrm{mM}$ $\mathrm{CaCl}_{2}$, and $4.3 \mathrm{mM} \mathrm{MnCl}_{2}$. The statistical optimization by RSM resulted in 1.5 fold increase in the protease activity by Bacillus aquimaris VITP4 strain. The enzyme showed a maximum half life of $267 \pm 18 \mathrm{~min}$ when incubated at $45^{\circ} \mathrm{C}$ at $\mathrm{pH} 8.0$ along with $\mathrm{CaCl}_{2}$ $(10 \mathrm{mM})$ and $\mathrm{MnCl}_{2}(5 \mathrm{mM})$. The properties of the protease unraveled in the present study would contribute to its utility in many industrial processes. 


\section{Conflict of interest}

The authors confirm that his article content has no conflict of interest.

\section{Acknowledgements}

C. Jabeena Thaz is a recipient of UGC-MAN Fellowship (201011-MANF-MUS-AND-1551) and B. Lavanya is a recipient of UGC-CSIR Fellowship (09/844(0010)/2012 EMR-I). The research facility provided by the VIT University (Vellore, India) is gratefully acknowledged.

\section{References}

1. Karan R, Capes MD, DasSarma S. Function and biotechnology of extremophilic enzymes in low water activity. Aquat Biosyst. 2012;8:1-15. DOI: 10.1186/2046-9063-8-4

2. Öztürk S, Ozeren-Morgan M, Dilgimen A, Denizci A, Arikan B, Kazan D. Alkaline serine protease from halotolerant Bacillus licheniformis BA17. Ann Microbiol. 2009;59:83-90. DOI: 10.1007/BF03175603

3. Gerard A Selleka, Julian B Chaudhuria. Biocatalysis in organic media using enzymes from extremophiles. Enzyme Microb Technol. 1999;25:471-482. DOI: 10.1016/S0141-0229(99) 00075-7

4. Kim JI, Lee SM, Jung HJ. Characterisation of calcium activated bifunctional peptidase of the psychrotrophic Bacillus cereus. J Microbiol. 2005;43:237-243.

5. Veloorvalappil NJ, Robinson BS, Selvanesan P, Sasidharan S, Kizhakkepawothail NU, Sreedharan S, Prakasan P, Moolakkariyil SJ, Sailas B. Versatility of microbial proteases. Adv Enzyme Res. 2013;1:39-51. DOI: 10.4236/aer.2013. 13005

6. Singh SK, Singh SK, Tripathi VR, Garg SK. Purification, characterization and secondary structure elucidation of a detergent stable, halotolerant, thermoalkaline protease from Bacillus cereus SIU1. Process Biochem. 2012;47:1479-1487. DOI: 10.1016/j.procbiio.2012.05.021

7. Badoei Dalfard A, Karami Z. Screening and isolation of an organic solvent tolerant protease from Bacillus sp. JER02. Activity optimization by response surface methodology. $J$ Mol Catal B Enzymatic. 2013;89:15-23. DOI: 10.1016/J.molcatb.2012.11.016

8. Deepak V, Kalishwaralal K, Ramakumarpandian S, Venkatesh Babu S, Senthil Kumar S R, Sangiliyandi G. Optimization of media composition for Nattokinase production by Bacillus subtilis using response surface methodology. Bioresour Technol. 2008;99:8170-8174. DOI: 10.1016/j.biortech.2008. 03.018

9. Ovissipour M, Abedian Kenari A, Motamedzadegan A, Nazari RM. Optimization of enzymatic hydrolysis of visceral waste proteins of yellow fin tuna (Thunnus albacares). Food Bioprocess Technol. 2012;5:696-705. DOI: 10.1007/s11947010-0357-x

10. Pooja S, Jayaraman G. Production of extracellular protease from halotolerant bacterium, Bacillus aquimaris strain VITP4 isolated from kumta coast. Process Biochem. 2009;44:1088-
1094. DOI: $10.1016 /$ j.procbio.2009.05.010

11. Pooja S, Jayaraman G. Isolation and characterization of a metal ion dependent alkaline protease from a halotolerant Bacillus aquimaris VITP4. Indian J Biochem Biophys. 2011;48:95100

12. Thaz CJ, Jayaraman G. Stability and detergent compatibility of a predominantly $\beta$-sheet serine protease from halotolerant B.aquimaris VITP4 strain. Appl. Biochem Biotechnol. 2014;172:687-700. DOI: 10.1007/s12010-013-0524-4

13. Yang JT, Wu CS, Martinez HM. Calculation of protein conformation from circular dichroism. Methods Enzymol. 1986;130:208-269.

14. Cupp Enyard C. Sigma's non specific protease activity assayCasein as a substrate. $J$ Visualized Exp. 2008;19:899. DOI: 10. 3791/899

15. Wu Y, Mao J, Mei L, Liu S. Studies on statistical optimization of sulforaphane production from broccoli seed. Electron J. Biotechnol. 2013;16:1-16. DOI: 10.2225/vol16-issue6-fulltext-16

16. Vijayaraghavan P, Gnana Prakash Vincent S. Statistical optimization of fibrinolytic enzyme production by Pseudoalteromonas sp. IIND11 using cow dung substrate by response surface methodology. Springer Plus. 2014;3:60. DOI: 10.1186/2193-1801-3-60

17. Muthuvelayudham R, Viruthagiri T. Application of central design based response surface methodology in parameter optimization and on cellulase production using agricultural waste. Int J Chem Biol Eng. 2010;3:97-104.

18. Zangué Desobgo SC, Emmanuel Nso J, Dzudie Tenin. Use of the response surface methodology for optimizing the action of mashing enzymes on wort reducing sugars of the Madjeru sorghum cultivar. Afr J Food Sci. 2011;5:91-99. DOI: 10. 1002/j.2050-0416.2010.tb00399.x

19. Usharani B, Muthuraj M . Production and characterization of protease enzyme from Bacillus laterosporus. Global J Mol Sci. 2009;4:180-186.

20. Ningthoujam DS, Kshetri P. A thermostable alkaline protease from a moderately halo alkalithermotolerant Bacillus subtilis strain SH1. Aust. J Basic Appl Sci. 2010;4:5126-5134. DOI: 10/2010; 4(10):5126-5134

21. Sharaf EF, Al-Fadel K. Green recycling of chicken feather and sheep wool using the partially purified alkaline protease from Bacillus circulans L. Nat Sci. 2013;5:25-29. DOI: 10.4236/ ns.2013.56A004

22. Eijsink VG, Matthews BW, Vriend G. The role of calcium ions in the stability and instability of a thermolysin like protease. Protein Sci. 2011;20:1346-1355. DOI: 10.1002/pro.670

23. Sinha R, Khare SK. Isolation of a halophilic Virgibacillus $s p$. EMB13, Characterization of its protease for detergent application. Indian J Biotechnol. 2012:11;416-426.

24. Queiroga AC, Pintado ME, Malcata FX. Use of response surface methodology to optimize protease synthesis by a novel strain of Bacillus sp. isolated from Portuguese sheep wool. $J$ Appl Microbiol. 2012;113:36-43. DOI: 10.1111/j.13652672.2012.05300.x

25. Cheng SW, Wang YF, Wanga ML. Statistical optimization of medium compositions for alkaline protease production by newly isolated Bacillus amyloliquefaciens. Chem Biochem 
Eng Q. 2012;26:225-231.

26. Moorthy IM, Baskar R. Statistical modeling and optimization of alkaline protease production from a newly isolated alkalophilic Bacillus species BGS using response surface methodology and genetic algorithm. Prep Biochem Biotechnol. 2013;43:293-314. DOI: 10.1080/10826068.2012.719850

27. Zheng Y, Chen Q, Shan A, Zhang H. Optimization of the Enzymatic Hydrolysis of Blood Cells with a Neutral Protease. Biomed Res Int. 2013;2013:Article ID 278927,1-10. DOI: $10.1155 / 2013 / 278927$

28. Radhika Tatineni, Kiran Kumar Doddapaneni, Ravi Chandra Potumarthi and Lakshmi Narasu Mangamoori. Optimization of keratinase production and enzyme activity using Response surface methodology with Streptomyces sp7. Appl Biochem Biotechnol. 2007;7:187-202. DOI: 10.1007/BF02729061

29. Amiza MA, Masitah M. Optimization of enzymatic hydrolysis of blood cockle (Anadara granosa) using Alcalase. Borneo Sci. 2012;31:1-8.

30. Mokashe N, Chaudhari A and Patil U. Optimal production and characterization of alkaline protease from newly isolated halotolerant Jeotgalicoccus sp. Biocatal Agric Biotechnol. 2015;4:235-243. DOI: 10.1016/j.bcab.2015.01.003

31. Sinsuwan S, Jangchud A, Rodtong S, Roytrakul S and Yongsawatdigul J. Statistical optimization of the production of $\mathrm{NaCl}$-tolerant proteases by a moderate halophile, Virgibacillus sp. SK37. Food Technol Biotechnol. 2015;53:136-145. DOI: 10.17113/ftb.53.02.15.4015

32. Sathishkumar R, Ananthan G and Arun J. Production, purification and characterization of alkaline protease by ascidian associated Bacillus subtilis GA CAS8 using agricultural wastes. Biocatal Agric Biotechnol. 2015;4:214-220. DOI: 10.1016/j.bcab.2014.12.003

33. Gupta R, Beg QK, Lorenz P. Bacterial alkaline proteases: molecular approaches and industrial applications. Appl Microbiol Biotechnol. 2002;59:15-32. DOI: 10.1007/s00253002-0975-y

34. Rao MB, Tanksale AM, Ghatge MS, Deshpande VV. Molecular and Biotechnological Aspects of microbial Proteases Microbiol. Mol Biol Rev. 1998;62:597-635.

35. Kumar CG, Takagi H. Microbial alkaline proteases, From a bioindustrial viewpoint. Biotechnol Adv. 1999;17:561-594. DOI: 10.1016/S0734-9750(99)00027-0

36. Vieille C, Zeikus GJ. Hyperthermophilic Enzymes, Sources, Uses and Molecular Mechanisms for Thermostability. Microbiol Mol Biol Rev. 2001;65:1-43. DOI: 10.1128/ MMBR.65.1.1-43.2001

37. Son ES, Kim JI. Multicatalytic alkaline Serine Protease from the Psychrotrophic Bacillus amyloliquefaciens S94. J Microbiol. 2003;41:58-62.

38. Ibrahim ASS, Al-Salamah AA, El-Badawi YB, El-Tayeb MA and Antranikian G. Detergent-, solvent- and salt-compatible thermoactive alkaline serine protease from halotolerant alkaliphilic Bacillus sp. NPST-AK15, purification and characterization. Extremophiles 2015;19:961-971. DOI: 10.1007/s 00792-015-0771-0

39. Ibrahim ASS, Al-Salamah AA, Elbadawi YB, El-Tayeb MA and Shebl Ibrahim SS. Production of extracellular alkaline protease by new halotolerant alkaliphilic Bacillus sp. NPST-AK15 isolat- ed from hyper saline soda lakes. Electron J Biotechnol. 2015;18:236-243. DOI: 10.1016/j.ejbt.2015.04.0 01

40. Coolbear T, Whittaker JM, Daniel RM. The effect of metal ions on the activity and thermostability of the extracellular proteinase from a thermophilic Bacillus, strain EA.1. Biochem J. 1992;287:367-374. DOI: 10.1042/bj2870367

41. Banerjee UC, Rajesh Kumar Sani, Wamik Azmi, Raman Soni. Thermostable alkaline protease from Bacillus brevis and its characterization as a laundry detergent additive. Proc Biochem. 1999;35:213-219. DOI: 10.1016/S0032-9592(99) 00053-9

42. Joo HS, Koo YM, Choi JW, Chang CS. Stabilization method of an alkaline protease from inactivation by heat, SDS and hydrogen peroxide. Enzyme Microb Tech. 2005;36:766-772. DOI: 10.1016/j.enzyictec.2005.01.002 